\title{
Analyzing The Use of Catholic Learning Model for the State Primary SCHOols In SOUTH AND SOUTheast PontianaK
}

\author{
Lukas Ahen $^{1)}$, Cenderato $^{2)}$, Florentina $^{3)}$, Florentina Dwi Astuti ${ }^{4)}$, Arius Arifman Halawa ${ }^{5)}$ \\ ${ }^{1)}$ STAKat Negeri Pontianak, Pontianak, Indonesia \\ E-mail: ahenlukas66@gmail.com \\ ${ }^{2)}$ STAKat Negeri Pontianak, Pontianak, Indonesia \\ E-mail: cenderato67@gmail.com \\ ${ }^{3)}$ STAKat Negeri Pontianak, Pontianak, Indonesia \\ E-mail: Flotina999@gmail.com \\ ${ }^{4)}$ STAKat Negeri Pontianak, Pontianak, Indonesia \\ E-mail:flodwi@gmail.com \\ ${ }^{5)}$ STAKat Negeri Pontianak, Pontianak, Indonesia \\ E-mail: Arif_hlw@yahoo.co.id
}

\begin{abstract}
Learning models were important for the teachers to apply by considering the class setting. How they could manage their class depending on what learning model they could apply. So, it was curious to know what learning model the teachers had used so far. To deal with this, the researchers were eager to find out the answer by the research. This study aims to describe the learning model, the advantages and disadvantages of using the model, and the efforts made by Catholic Education (PAK) teachers in overcoming the disadvantages and strengths of using models in the State Primary Schools in South and Southeast Pontianak. To see the use of the learning model, qualitative research methods were used which consisted of interviews, questionnaires, observations, and focus group discussions. Teachers in the State Elementary Schools in South and Southeast Pontianak had implemented the learning models: Inquiry Model, Story Telling, Role Play, and Discovery Learning contextually. Based on the result, the teacher had a strategy in the application of learning models for example: reading books that are relevant to the model to apply, inviting students to learn outside the room, taking a persuasive and personal approach. Meanwhile, some obstacles faced were the delinquency of students, less in number, a variety of competencies, the existence of students with special needs, and the lack of teaching aids. The advantages of using the learning model were systematic, involving students actively, creating cooperation, motivating students, and improving learning outcomes. The learning model tended to run monotonously. There were several efforts to overcome deficiencies of learning models: taking a personal approach, trying to maximize the use of learning models used, changing models learning that would be considered more suitable or repetitive by applying the same learning model to maximize learning outcomes, conveying material repeatedly, writing student names and adding value to students who are active in groups so they try to want to be active, giving additional assignments to students who have understood learning so students do not have to be in class and trying to maximize the tools and means of learning that exist and do to students.
\end{abstract}

Keywords: Learning Model; 2013 Curriculum; Catholic Education 


\section{INTRODUCTION}

Catholic Education is a planned and continuous effort to develop the ability of students to strengthen faith and devotion to God Almighty in accordance with the teachings of the Catholic Church, while still paying attention to respect for other religions in the relationship between religious harmonies and national unity.

Religion education in schools does not merely make students to have faith but to educate students to be able to account for their faith with the knowledge they have. The knowledge is obtained based on the results of learning in schools according to the demands of K-13 which emphasizes character education. Learning is an effort of the teacher to provide stimulus, guidance, direction, and encouragement to students so that the learning process occurs. Learning in this case is not a process of providing knowledge, but the process of forming knowledge by students and for students through the optimization of cognitive performance.

Based on information obtained from the elementary level; PAK supervisors, researchers found a lack of teacher creativity in using learning models, specifically StudentCentered learning models in Pontianak City Elementary School. Teachers are more likely to use a monotonous Conventional (lecture) model so that students are less interested in the learning process, so researchers analyze the use of Learning Models by PAK Teachers in Elementary Schools in South and Southeast Pontianak. This can map the use of various learning models by PAK Teachers in Pontianak State Elementary School. The results of this mapping will be very useful for the evaluation of PAK learning, which will then offer a Learning Model that is following the characteristics of learners in South and Southeast Pontianak.

According to Abidin (2014: 1), learning is a process built by teachers to develop thinking creativity that can improve students' abilities in constructing new knowledge as an effort to improve good mastery of subject matter. Learning describes a dynamic process because in essence learning behavior is realized in a dynamic process and not something silent or passive. The 2013 curriculum stressed that character education is very important. Character education is taught using several learning models including Inquiry Learning (Discovery), Problem Based Learning, and Project-Based Learning. Komalasari (2011) stated that a learning model is a form of learning illustrated from beginning to end that is presented typically by the teacher.

The Inquiry-Learning Model (inquiry) is one of the very constructive teaching models. Inquiry learning is a series of learning activities that maximally involve all students' abilities to search and investigate systematically, critically, logically, analytically, so that students can formulate their findings with confidence. The Inquiry Learning Model is a learning developed model so that students find and use various sources of information and ideas to increase their understanding of a particular topic, problem, or issue. In this model, the teacher acts as a partner or guide in learning, facilitating, and guiding student learning experiences to achieve certain goals that have been set. Hamzah (2012) explained that at first this model was used for learning science but subsequently learning models can be used for all subjects. All topics can be used as a problem to find the right solution and true, to train students to think scientifically. Lee May (2014) mentioned:

"Inquiry-based learning (IBL) is a method of instruction that places the student, the subject, and their interaction at the center of the learning experience. At the same time, it transforms the role of the teacher from that of dispensing knowledge to one of facilitating learning. It repositions him or her, physically, from the front and center of the classroom to someplace in the middle or back of it, as it subtly yet significantly increases his or her involvement in the thought-processes of the students".

Warner and Myer (2011) strengthen teachers play a vital role in adapting the inquiry process to the knowledge and ability level of their students. When using inquiry-based lessons, teachers are responsible for (1) starting the inquiry process, (2) promoting student dialog, (3) transitioning between small groups and classroom discussions, (4) intervening to clear misconceptions or develop student's understanding of content material, (5) modeling scientific procedures and attitudes, and, (6) utilizing student experiences to create new content knowledge.

Learning one's design students to be active in learning activities, such as observing, discuss, ask, argue, and so on, will give a positive impact on students. For that reason, especially in the learning process in learning the need for student activity through inquiry activities.

The inquiry model is an interdisciplinary learning model that functions to familiarize students with learning and solving problems, think critically and assume, and be responsible for achieving understanding independently.

The learning model Discovery Learning has characteristics that are characteristic of other learning models. The Discovery Learning model has the principles of a) the principle of interaction and asking, b) the principle of learning to think, c) learning based on what it already knows, d) learning through learning and experience following the level of development of knowledge, and e) oriented towards intellectual development.

The project-based learning model (Project Based Learning) is a learning model that directly engages students in the learning process through research activities to work on and complete a particular learning project. Goodman and Stivers (2010) explained that teaching approaches that are built on learning activities and real assignments that provide challenges for students related to daily life to be solved in groups.

According to Abidin (2014: 167), the Project-Based Learning model is a learning model that is used to develop a variety of basic skills that students must have, including thinking skills, decision-making skills, creative abilities, problem-solving abilities and at the same time considered effective for developing self-confidence and self-management in students. Surya (2013: 111), "learning is a translation of learning" which comes from the word "learn" or" to learn ". According to Afriana (2015), Project-Based Learning model Project-based learning is a learning model that is studentcentered and provides meaningful learning experiences for 
students. Learners' learning experiences and concepts are built based on the products produced in the project-based learning process. Learning models provide opportunities for educators to manage learning in class by involving project work. Project work is a form of work that contains complex tasks based on questions and problems that are very challenging and guide students to design, solve problems, make decisions, conduct investigative activities, and provide students the opportunity to work independently.

Utami (2014) stated that Problem Based Learning (PBL) is a learning model that provides real experiences that encourage students to learn actively, construct knowledge, and integrate the context of learning in school and learn real-life in real life naturally. This model places problematic situations at the center of learning, attracting students to learn. Students are directly involved in solving problems, identifying problems, and producing solutions. Teachers are required to be able to choose learning models that can stimulate the enthusiasm of each student to be actively involved in their learning experiences. One alternative learning model that allows the development of students' thinking skills (reasoning, communication, and connections) in solving problems is Problem Based Learning (PBL). Abidin (2014: 161) mentioned that Problem Based Learning (PBL) has characteristics, namely (a) Learning begins with a problem, (b) Ensures the problem given is related to the real world of students, (c) Organizing lessons in around problems, not around disciplines, (d) giving full responsibility to students in experiencing first hand their learning processes, (d) using small groups, and (e) Demanding students to demonstrate what they have learned in the form of products or performance.

Relating to the explanation above, there are three problems would be examined in this study, namely; how is the learning model used by Catholic Education (PAK) teachers in State Primary Schools in South and Southeast Pontianak, what are the advantages and disadvantages of using the learning models that have been applied so far and what are the efforts made by Catholic Education Teachers (PAK) to overcome the lack of use of learning models that have been applied so far. The initial step of the study was that the research team contacted the PAK supervisor at the Pontianak City level as a source of information. The involvement of Basic Level PAK Supervisors (SD) was not new because the previous research team (2018) had contributed related to secondary data in Pontianak City. The Research Team is one of the entry points involved in the activities of the Catholic Education Teacher Working Group (KKG PAK) held by PAK teachers in South and Southeast Pontianak State Primary Schools.

\section{Methodology}

This study was using a descriptive qualitative method. Sugiyono (2013) mentioned that qualitative research methods are based on the philosophy of post-positivism used to examine natural conditions of objects, where the researcher is a key instrument, data collection techniques with triangulation, qualitative data analysis, and qualitative research results emphasize meaning rather than generalization.
It had several sets of activities to obtain data following the actual situation whose results emphasize more meaning. The study carried out some of the steps of conducting initial observations in the study of literature and field observations, then determining the research problem. The next step was data collection conducted by researchers assisted by Catholic Education teachers who teach at State Primary Schools in South and Southeast Pontianak. To collect the data, the researchers applied the triangulation technique. Sutama (2010: 101) explained that triangulation is a technique checking the validity of data that uses something else outside the data for the need to check or as a comparison of the data, namely: the interview technique, the field observations, the documentation studies and research instruments used in the form of a questionnaire to see the use of learning models used during the teacher's teaching. After collecting the data, the researchers analyzed it and made a discussion.

The method used in this study was a qualitative description of the phenomena that occur during the process with the subject of Catholic Education (PAK) teachers and students at the Elementary School (SD) level in South and Southeast Pontianak. The initial step of the study was that the research team contacted the PAK supervisor at the Pontianak City level as a source of information. The involvement of Basic Level PAK Supervisors (SD) was not new because the previous research team (2018) had contributed related to secondary data in Pontianak City. The Research Team is one of the entry points involved in the activities of the Catholic Education Teacher Working Group (KKG PAK) held by PAK teachers in South and Southeast Pontianak State Primary Schools. Regarding data collection techniques, the research team conducted in-depth interviews and observations of PAK teachers. For primary data collection, researchers used Focused Group Discussion (FGD) and interview techniques, as one of the methods used to obtain data. Through the FGD, a meeting was held with religion teachers and various related parties to obtain further input on how PAK learning is practiced, perceived, and defined by PAK teachers at State Primary Schools in South and Southeast Pontianak.

Through the interview technique, the researchers obtained verbal information from informants (teachers, students, and other related parties). Interviews were in form of a semistructured manner, assisted by interview guidelines as a means of collecting data with informants selected both purposive and snowball. To strengthen the data obtained, researchers also make observations, both involved (participant observant) or not, and documentation. This stage used observation guidelines, field notes, and recording as a data collection tool. For secondary data collection, researchers conducted a literature study (library research) and documentation (learning kit) by collecting relevant data.

Analyzing the data was starting by entering the field, on the field, and after being on the field. Before entering the field, an analysis was carried out on the results of the preliminary study (secondary data). Field analysis carried out during data collection, and after the data, collection completed within a certain period. At the time of the interview, the researcher had to analyze the answers of the 
interviewees. If after analyzing the informant's answers have not been satisfactory, the researcher asked more questions until at a certain stage credible data obtained. Analyzing the data interactively and continues until the data is saturated. Activities in data analysis included data reduction, data display, and conclusion.

\begin{tabular}{|c|c|c|c|}
\hline $\begin{array}{l}\text { Input } \\
\text { Various } \\
\text { Learning } \\
\text { Model }\end{array}$ & $\begin{array}{l}\text { Process } \\
\text { Impleme } \\
\text { nt } \\
\text { Learning } \\
\text { Model }\end{array}$ & $\begin{array}{l}\text { Output } \\
\text { Mapped } \\
\text { learning } \\
\text { models } \\
\text { used by } \\
\text { PAK } \\
\text { Element } \\
\text { ary } \\
\text { School }\end{array}$ & $\begin{array}{l}\text { Outcome } \\
\text { increasing } \\
\text { the ability } \\
\text { of PAK } \\
\text { teachers } \\
\text { to use } \\
\text { learning } \\
\text { models as } \\
\text { neededSc }\end{array}$ \\
\hline
\end{tabular}

Fig. 1 Research flow chart

\section{RESULTS AND DISCUSSION}

The teacher in the learning process has a very important role including as a source of learning, facilitator, manager, demonstrator, guide, motivator, and evaluator. As a facilitator, the teacher plays a role in providing services to facilitate students in learning.

To meet the teacher's criteria as a facilitator, then teaching and learning activities require a learning model that interests students. The learning model is planning that contains a series of activities designed to achieve educational a certain goal. Criteria for choosing a learning model used in the learning process must be oriented towards the learning objectives to achieve. It also must be adjusted to the type of material, characteristics of students, as well as the situations or conditions in which the learning process is going.

Learning Models in Catholic Education (PAK) Subjects in Public Elementary Schools in South and Southeast Pontianak was also the focus of attention by researchers. Based on information obtained from the interviews, the respondents have implemented learning models in the classroom with a variety of models with different patterns. The learning model used for example Model Inquiry, storytelling, role-play, and discovery learning. The reason the teachers use the learning model is that the learning models used are compatible with the character of students because they are easy to understand and apply in class. Besides, the learning models applied are also interesting so that students are not easily bored.

Teachers should use learning models to achieve learning targets following the context of the material to teach. This deals with Utami (2014) stated that a learning model provides real experiences that encourage students to learn actively, construct knowledge, and integrate the context of learning in school and learn real-life in real life naturally. This model places problematic situations at the center of learning, attracting students to learn. The selection of learning models must be able to adapt to the situations and conditions of learning in the classroom and must be precise so that what was to achieve in learning could be aware properly and the selection of learning models should be able to motivate students. Based on the results of interviews with several PAK teachers, there are several answers obtained and can be analyzed.

Some Catholic Education teachers in State Elementary Schools in South and Southeast Pontianak have implemented contextual learning models so that they meet the provisions of the 2013-Curriculum and can make students think critically. In applying the learning model, certain strategies were very necessary so that the teacher could apply the learning model as well.

PAK teachers had a specific strategy that was more or less the same as the others; first: read books related to the learning model that was applied to students. By digging as much information on the learning model, they could find out the weaknesses and strengths of using the models, that they could evaluate it based on the situation and condition of students. Afriana (2015), teachers should apply student-centered and provides meaningful learning experiences for students. Second, study outdoors. On certain occasions, they tried new things by inviting students to learn outside the room, in this way, students might get different settings and environments in the teaching and learning process. The majority of informants said that this strategy was effective, where students were more enthusiastic in the teaching and learning process. Third, take a personal approach. If some students find it difficult to accept the learning model, the teacher takes a personal approach by exploring the problem, whether the learning model applied is not suitable for them or from the individual students who are not motivated to learn. If the learning model applied is not suitable, then the PAK teacher concerned would look for other learning models, but if the problem was with the individual students, the PAK teacher pays special attention to the students.

The ability of students to accept PAK lessons using the learning model must also be the focus of the teacher, meaning that the application of the model should be acceptable to make the learning atmosphere more conducive. From the results of interviews about the development of students' ability to accept PAK lessons based on the learning model, they applied, almost all respondents said there was progress because they made a personal approach. This result was from the results of the task, midterm, or final test. Through the results of this evaluation, PAK Teachers can find out the strengths and weaknesses that students have and can know the methods used in teaching so that students are easy to understand the lessons delivered. The PAK teachers carried out this evaluation based on the material provided to students so that in the evaluation system it will be easier for them to find out students who do not understand the learning delivered according to the evaluation system that they do.

Students had diverse characteristics, some were active and some are passive in-class activities, so what teachers did to deal with students who tended to be passive in the teaching and learning process is discussion. In this way, students were allowed to express their opinions among their peers. The teacher to control the atmosphere of the discussion always guided the discussion process. The teacher requires all students to speak even if only one sentence. 
Student creativity was very necessary for implementing the learning model. Some students worked together, enthusiastic about solving problems, and then ask if there is something, they did not understand. However, in some other schools, some students are ignorant in following the learning process, especially in problem-solving activities, so some students had not been able to solve problems, some students were uncreative because of the different abilities of students.

In the application of the learning model, there were certain constraints faced by teachers both internally and externally. Abidin (2014: 161) mentioned that Problem Based Learning (PBL) has characteristics, namely (a) Learning begins with a problem, (b) Ensures the problem given is related to the real world of students, (c) Organizing lessons in around problems, not around disciplines, (d) giving full responsibility to students in experiencing first hand their learning processes, (d) using small groups, and (e) Demanding students to demonstrate what they have learned in the form of products or performance. Internally, it could come from the teacher concerned because of limited knowledge of the learning model to apply. Externally, for example, came from students. Based on the results of the interview, it was found that the obstacles in applying the learning model were dealing with the delinquency of students, the relatively small number of students, various competencies, and presence of students with special needs, and the lack of teaching aids. While the solutions to these obstacles for example using a persuasive approach, repeating the material previously presented, taking a personal approach, and try to give questions to students in turn so that all are active in speaking.

PAK teachers should know the strengths and weaknesses of the learning model to improve the use of the model. Because the use of learning models tends to be systematic so that it involves students actively, cooperation, motivating students, and subject matter more easily remembered. However, often the application of the learning model tends to be monotonous, students prefer the lesson to finish quickly, grades are better, the learning model should be prepared as early as possible to anticipate deficiencies at the time of its application, noisy classroom atmosphere and spend a lot of time.

After carrying out learning, the teacher had to evaluate or reflect on learning activities to determine the level of achievement. Teachers should make various efforts in overcoming weaknesses or deficiencies in classroom learning, especially in applying the learning model to certain subjects. Based on the results of the interview (Question 13), there were efforts to overcome deficiencies in using learning models applied so far. For example, by (a) taking a personal approach, (b) trying to maximize the use of the learning model used, (c) replacing the learning model presumably more suitable or repeated by applying the same learning model to maximize learning outcomes, (d) conveying material over and over (2 opinions), (e) writing students' names and adding value to students who are active in groups so they try to willing to be active, (f) giving additional assignments to students who have understood learning so students do not seize in class and $(\mathrm{g})$ try to maximize the existing learning tools and facilities and taking a personal approach to students.

Providing peer assessments for students is also an effort to overcome deficiencies in the application of learning models in PAK, where students interact with each other and discuss in groups and outside groups. Obstacles or weakness in applying the learning model was a challenge.

In the process of using the learning model, many of the challenges faced by teachers including (a) the challenges of non-Catholic students (there are Buddhist students taking part in Catholic studies), who did not have a Catholic Education background. It was very difficult to apply existing learning models that in accordance with available learning material, (b) requiring careful preparation and a long time to master the steps of applying the learning model, (c) looking for a learning model that is suitable with the material that is able to create interesting and fun learning and ultimately improve student learning outcomes, (d) should know in detail the steps of each learning model so that learning becomes more effective and effective, (e) preparing the material carefully so that its application can proceed based on the plan, (f) taking too much time so learning targets are unachievable because they are not all students heed all that is said, $(\mathrm{g})$ in the learning process, when applying one of the learning models students become hurt by the teacher because they were sanctioned for violations they did so the teacher was challenged to melt the hearts of their students so they want to forgive their teacher, (h) only few students in one class and inadequate room (not in the classroom but in one of the nonstandard spaces).

Related to the suitability of the material used for students outside of Pontianak, respondents' answers varied, for different reasons. Some respondents considered that materials were suitable for the reason of no striking differences between students in Pontianak and students in rural areas. Others said for classes in schools outside of Pontianak because there was no difference in the quality of students in the city or in the area/hinterland proven when students from the region continue their studies in Pontianak was able to compete and there were even more achievers than students in Pontianak. Another opinion was that some material was suitable to apply both in Pontianak and in the regions but some material was not suitable because it was too heavy and difficult to understand by students in the area. Next, some said that the existing material to adjust to the conditions in the area so that it was also suitable for students in the city or remote areas. Last, the material was unsuitable for outside of Pontianak: there was a language barrier (students are not fluent in Indonesian), students do not attend school at the Kindergarten level.

\section{CONCLUSIONS}

Based on the discussion in the previous chapter, teachers in the State Elementary Schools in South and Southeast Pontianak had implemented the learning models: Inquiry Model, Story Telling, Role Play, and Discovery Learning contextually. Then, the teacher also had a strategy in the application of learning models for example: reading books that are relevant to the model to apply, inviting students to 
learn outside the room, taking a persuasive and personal approach when there are students who have problems in learning. However, there were some obstacles faced when the application of these models namely the delinquency of students, the number of students is relatively small, the variety of competencies, the existence of students with special needs, and the lack of teaching aids. The advantages of using the learning model were systematic, involving students actively, creating cooperation, motivating students, and improving learning outcomes. Weaknesses of the learning model were monotonous, the learning model must be prepared as early as possible to anticipate deficiencies when applying it and the noisy classroom atmosphere and the implementation of the learning model spend a lot of time while students prefer the learning process to finish quickly. There were several efforts to overcome deficiencies of learning models for example by taking a personal approach, trying to maximize the use of learning models used, changing models learning that would be considered more suitable or repetitive by applying the same learning model to maximize learning outcomes, conveying material repeatedly, writing student names and adding value to students who are active in groups so they try to want to be active, giving additional assignments to students who have understood learning so students do not have to be in class and trying to maximize the tools and means of learning that exist and do to students.

\section{ACKNOWLEDGMENT}

This research was funded through 2019 Applied Research with contract number 66 in Year-2019 dated July 29, 2019, therefore many thanks were expressed to the STAKat Negeri Pontianak. We would also like to thank the validator who worked hard to examine the contents of this textbook and provide many suggestions.

\section{REFERENCES}

Abidin Y. (2014). Desain system pembelajaran dalam konteks kurikulum 2013. Bandung: PT. Refika Aditama.

Afriana, Jaka. (2015). Project Based Learning (PjBL). Makalah untuk Tugas Mata Kuliah Pembelajaran IPA Terpadu. Program Studi Pendidikan IPA Sekolah Pascasarjana. Universitas Pendidikan Indonesia. Bandung.

Goodman, Brandon, and Stivers, J. (2010). Project-Based Learning. Educational Psychology. ESPY 505.

Hamzah, B. Uno. (2012). Model Pembelajaran: Menciptakan Proses Belajar Mengajar yang Kreatif dan Efektif. Jakarta: PT. Bumi Aksara.

Komalasari, K. (2011). Pembelajaran Kontekstual Konsep dan Aplikasi. Bandung: PT. Rafika Aditama.

Lee May, Everette. (2014). What is IBL? http://www.inquirybasedlearning.org/?page $=$ What_is _IBL (Accessed on December 20, 2014).

Mohamad, S. (2013). Psikologi Guru Konsep dan Aplikasi. Bandung: CV Alfabeta.
Sugiyono. (2013). Memahami Penelitian Kualitatif. Bandung: CV. Alfabeta.

Sutama. (2010). Penelitian Tindakan Teori Dan Praktek dalam PTK, PTS, dan PTBK. Semarang: CV. Citra Mandiri Utama.

Utami, Rini. (2013), Model Pembelajaran Berbasis Masalah dengan Langkah Penyelesaian Berdasarkan Polya dan Krulik-Rudnick Ditinjau dari Kreativitas Siswa. Jurnal Ilmiah Pendidikan Matematika, 1(1):81-96.

Warner, Anna J. dan Myer, Brian E. (2011). What Is InquiryBased Instruction?. http://edis.ifas.ufl.edu/pdffiles/WC/WC07600.pdf (Accessed on December 20, 2014). 